\title{
Hubungan antara Problematic Internet Use dengan Prokrastinasi Akademik
}

\author{
Annisa Risqi Anggunani ${ }^{1}$ \& Budi Purwanto ${ }^{2}$ \\ Fakultas Psikologi Universitas Gadjah Mada
}

\begin{abstract}
This study aims to find out the relationship between problematic internet use (PIU) and academic procrastination in college students. This study took place in the Faculty of Psychology, Universitas Gadjah Mada with 190 students as the participants. The data were collected using Academic Procrastination Scale (APS) and Generalized Problematic Internet Use-2 (GPIUS2) that has been adapted in Bahasa. Hypothesis is analyzed using Pearson's product-moment correlation which shows that there is a positive relationship between problematic internet use and academic procrastination $(r=0,478 ; p=0,000(p<0,01)$. Furthermore, additional analysis shows that there is no different level in problematic internet use and academic procrastination based on gender. Other than that, there is also a no different level of academic procrastination based on the duration of internet usage in one day. Conversely, there is a different level of problematic internet use based on the duration of internet usage in one day.
\end{abstract}

Keywords: academic procrastination; college student; problematic internet use

Abstrak. Penelitian ini bertujuan untuk mengetahui hubungan antara problematic internet use (PIU) dengan prokrastinasi akademik pada mahasiswa. Penelitian berlangsung di Fakultas Psikologi Universitas Gadjah Mada dengan subjek penelitian sebanyak 190 mahasiswa. Data dikumpulkan menggunakan alat ukur berupa Academic Procrastination Scale (APS) dan Generalized Problematic Internet Use-2 (GPIUS2) yang sudah diadaptasi dalam Bahasa Indonesia. Hipotesis dalam penelitian ini dianalisis menggunakan pearson's product-moment correlation yang menunjukkan hasil bahwa terdapat hubungan positif yang signifikan antara problematic internet use dengan prokrastinasi akademik pada mahasiswa dengan $r=0,478$ dan taraf signifikansi $\mathrm{p}=0,000(\mathrm{p}<0,01)$. Analisis tambahan menemukan bahwa tidak ada perbedaan tingkat problematic internet use dan prokrastinasi akademik pada mahasiswa perempuan dan laki-laki. Selain itu, tidak ditemukan perbedaan tingkat prokrastinasi akademik yang signifikan berdasarkan durasi penggunaan internet dalam satu hari. Sebaliknya, ditemukan perbedaan problematic internet use yang signifikan berdasarkan durasi penggunaan internet dalam satu hari.

Kata kunci: mahasiswa; problematic internet use; prokrastinasi akademik

Mahasiswa dihadapkan pada berbagai proses belajar. Menurut Solomon dan aktivitas akademik di kampus seperti tugas Rothblum (1984) banyaknya tugas dengan individu, tugas kelompok, dan sistem berbagai macam karakteristik yang tidak pendidikan di kampus yang mengharuskan dapat diprediksi membuat mahasiswa mahasiswa untuk berperan aktif dalam seringkali merasa enggan untuk menger-

\footnotetext{
${ }^{1}$ Korespondensi mengenai isi artikel ini dapat dilakukan melalui annisaanggunani13@gmail.com

2 atau melalui budi.purwanto @ugm.ac.id
} 
jakan tugas karena munculnya keyakinan tidak rasional mengenai kemampuan dirinya dan perasaan takut akan kegagalan yang akan menimpanya. Dikemukakan oleh McCloskey (2011) bahwa kecenderungan untuk mengesampingkan atau menunda aktivitas dan perilaku yang berkaitan dengan tugas akademik sering disebut dengan prokrastinasi akademik. Burka dan Yuen (2008) mengestimasikan pada tahun 2007 terjadi peningkatan perilaku prokrastinasi yang dilakukan oleh mahasiswa yaitu sebanyak $75 \%$, dengan $50 \%$ mahasiswa mengatakan bahwa mere-ka melakukan prokrastinasi dan merasa perilaku tersebut adalah masalah baginya. Sementara itu, penelitian yang dilakukan oleh Negara (2013) pada 49 mahasiswa program sarjana dan 41 mahasiswa magister sains Fakultas Psikologi Universitas Gadjah Mada menemukan hasil bahwa subjek program sarjana paling banyak berada pada tingkat prokrastinasi akademik sedang $(25,6 \%)$, begitu pula subjek program magister paling banyak berada pada tingkat prokrastinasi akademik sedang (33,3\%).

Prokrastinasi akademik tidak lepas dari kegagalan regulasi diri individu seperti fokus yang terganggu, organisasi yang buruk, rendahnya motivasi berprestasi, dan adanya kesenjangan antara rencana dan realita. Prokrastinator cenderung memiliki organisasi yang buruk karena tidak dapat mengelola fokusnya yang terganggu karena hal yang lebih menyenangkan. Motivasi berprestasi yang rendah membuat prokrastinator tidak berhasil menjalankan rencana yang sudah disusun sebelumnya karena tidak memiliki motivasi. Hal ini menyebabkan adanya kesenjangan antara rencana dan realita yang dilakukan (Steel, 2007). Steel dan Klingsieck (2015) menambahkan bahwa secara spesifik, prokrastinator nampak memiliki kekurangan dalam strategi manajemen waktu, mudah terdistraksi oleh kesempatan yang atraktif, dan memiliki strategi belajar yang lemah. Prokrastinasi akademik dapat berdampak buruk pada pencapaian dan kesejahteraan subjektif siswa, seperti menghasilkan stres dan penyesalan.

Knaus (2010) menyatakan bahwa prokrastinasi akademik dilakukan karena individu menghindari ketegangan berkaitan dengan ketidaksukaan dalam aktivitas akademik. Saat seseorang tidak suka melakukan suatu pekerjaan, ia akan cenderung mengesampingkannya, dengan cara menunda untuk memulai pekerjaan atau menunda untuk menyelesaikan pekerjaan. Hal ini menyebabkan seseorang tidak melakukan tugasnya hingga terus menerus mengulang perilaku menunda pekerjaan. Perilaku penundaan ini tidak lepas dari pandangan individu terhadap kemampuan dirinya yang mereka percayai mampu bekerja di bawah tekanan. Hal ini seringkali menjadi penyebab prokrastinasi akademik yang membuat mereka menunda-nunda pekerjaan hingga menumpuk.

University of Illinois Counseling Center, 1996 (dalam Santrock, 2008) menemukan bahwa prokrastinasi memiliki beberapa bentuk, salah satunya adalah menghabiskan waktu berjam-jam untuk bermain komputer dan menjelajah internet. Ferrari, Johnson, dan McCown (1995) mengindikasi prokrastinasi dengan menghindari tugas untuk meredakan kecemasan yang merupakan respon umum terhadap tugas yang ada karena keengganan mengerjakan tugas atau ketakutan akan kegagalan. Prokrastinator yang berusaha menghindari ketegangan berusaha untuk mencari hiburan yang dapat meredakan ketegangan atau bahkan kecemasannya, salah satunya melalui internet. Hal ini selaras dengan penelitian Lavoie dan Pychyl (2001) yang menyatakan bahwa internet dianggap sebagai hiburan dan berhubungan positif dengan menghilang-kan rasa stres yang dirasakan seseorang. Penelitian ini mendukung penelitian sebelumnya yang menyatakan bahwa menghilangkan rasa 
stres adalah motivasi yang menonjol untuk menghindari tugas.

Davis (2001) menyatakan bahwa individu yang tidak bisa mengontrol penggunaan internetnya cenderung menggunakan internet dengan durasi yang terlalu lama dan tanpa alasan yang jelas sehingga mengakibatkan penundaan tugas yang tidak realistis. Diomidious et al., (2016) menambahkan bahwa penggunaan internet yang berlebihan dapat menyebabkan memburuknya hubungan dengan teman dan keluarga, kurangnya minat dalam kehidupan sehari-hari, pengabaian tugas rumah tangga, akademik, dan professional. Proses ini mendorong seseorang untuk menunda pekerjaan dan terdistraksi oleh internet yang dapat menyebabkan masalah akademik, sosial, keuangan, bahkan penurunan kondisi kesehatan. Beberapa peneliti bahkan mengaitkan penggunaan internet dengan permasalahan psikologis seperti depresi dan kesepian (Chen dan Peng, 2008).

Penggunaan internet yang menyebabkan hambatan dalam hal psikologis, sosial, akademik, dan atau pekerjaan di kehidupan seseorang disebut sebagai problematic internet use atau penggunaan internet bermasalah (Beard dan Wolf, 2001). Thatcher, Wretschko, dan Fridjhon (2008) menambahkan bahwa penggunaan internet yang berlebihan ini menjadi salah satu tanda bahwa individu merasa bosan, tidak termotivasi, dan tidak yakin akan kemampuannya untuk melaksanakan tugas di dunia nyata sehingga individu melarikan diri dari pekerjaannya menuju internet.

Hal menarik yang muncul dalam survey pra-penelitian ini adalah semua responden mengatakan bahwa mereka biasa melakukan prokrastinasi dengan menghabiskan waktu berjam-jam menggunakan internet. Rata-rata para responden menghabiskan waktu untuk menggunakan internet sekitar 6-10 jam setiap harinya. Para responden memilih internet sebagai bentuk prokrastinasi mereka karena mudah diakses, effortless, adiktif, dan bisa memperoleh berbagai informasi dunia luar serta kebahagiaan secara instan darinya. Responden melihat internet sebagai hal yang lebih menarik dibandingkan tugas-tugasnya. Dikemukakan oleh Lavoie dan Pychyl (2001) bahwa menunda pekerjaan melalui penggunaaan internet diharapkan dapat menghilangkan stres secara sementara melalui distraksi yang menarik.

Brate (2017) dalam penelitiannya yang melibatkan 111 mahasiswa Rumania dan 100 siswa sekolah menengah di Rumania menemukan alasan penggunaan internet secara berlebihan dan perilaku prokrastinasi. Penelitian Brate (2017) menemukan bahwa terdapat tiga alasan utama penggunaan internet berlebihan, yakni ketakutan akan kegagalan, kecemasan, dan keengganan untuk mengerjakan tugas. Sementara itu, empat alasan utama prokrastinasi adalah rasa malas, keengganan mengerjakan tugas, ketakutan akan kegagalan, dan perfeksionisme.

Penelitian yang dilakukan oleh Thatcher, et al. (2008) menemukan bahwa problematic internet use memiliki hubungan positif dengan prokrastinasi internet. Semakin tinggi tingkat problematic internet use, maka akan semakin tinggi pula prokrastinasi akademik. Begitu pula jika tingkat problematic internet use rendah maka tingkat prokrastinasi internet akan semakin rendah. Problematic internet use cenderung akan, muncul ketika internet digunakan untuk keperluan sosial daripada keperluan yang terkait pekerjaan. Sejalan dengan penelitian ini, Mohammadi, Tahriri, dan Hassaskhah (2015) memperoleh hasil bahwa ada hubungan yang moderat antara penggunaan internet bermasalah dan prokrastinasi akademik pada mahasiswa EFL di University of Guilan. Penggunaan internet bermasalah disimpulkan bisa men-jadi indikator dari prokrastinasi akademik pada mahasiswa EFL ini. 
Penelitian ini bertujuan untuk mengetahui hubungan antara problematic internet use dengan prokrastinasi akademik pada mahasiswa. Hipotesis yang diajukan adalah terdapat hubungan positif antara problematic internet use dengan prokrastinasi akademik pada mahasiswa. Semakin tinggi tingkat problematic internet use, semakin tinggi pula tingkat prokrastinasi akademik pada mahasiswa. Sebaliknya, semakin rendah tingkat problematic internet use, semakin rendah pula tingkat prokrastinasi akademik pada mahasiswa.

\section{Metode}

Subjek dalam penelitian ini adalah mahasiswa S1 Fakultas Psikologi UGM berjumlah 190 yang terdiri dari 151 perempuan dan 39 laki-laki. Subjek mayoritas berasal dari angkatan 2018 yaitu sebanyak 147 subjek. Ditinjau dari usia, diketahui bahwa sebagian besar subjek berusia 18 tahun sebanyak 101 . Sebanyak 79 subjek menghabiskan waktu untuk menggunakan internet dengan durasi 7-9 jam dalam satu hari.

Variabel independen pada penelitian ini adalah problematic internet use, sementara variabel dependennya adalah prokrastinasi akademik. Penelitian dilakukan dengan penyebaran skala paper-based yang dilakukan di dalam kelas paralel. Instrumen yang digunakan dalam penelitian ini terdiri dari dua skala yaitu skala adaptasi dari Generalized Problematic Internet Use Scale 2 (GPIUS-2) untuk mengukur problematic internet use dan skala adaptasi dari Academic Procrastination Scale (APS) untuk mengukur prokrastinasi akademik.

Skala Generalized Problematic Internet Use Scale 2 (GPIUS-2) disusun oleh Caplan (2010) berdasarkan aspek-aspek pathological internet use yang dikemukakan oleh Davis (2001) yang meliputi preference for online social interaction (POSI), mood regulation, deficient self-regulation yang terdiri dari cognitive preoccupation dan compulsive inter-net use, serta negative outcomes. Skala ini pernah diadaptasi dan digunakan dalam penelitian Sugiarto (2017) dan akan dimodifikasi pilihan jawabannya dalam penelitian ini. Skala adaptasi GPIUS-2 memiliki 15 aitem favorable, dengan skala mirip skala Likert yang memiliki lima pilihan yang meliputi Sangat Tidak Sesuai (STS), Tidak Sesuai (TS), Netral (N), Sesuai (S), dan Sangat Sesuai (SS). Skala ini memiliki skor koefisien reliabilitas sebesar 0,855 .

Peneliti mengadaptasi Academic Procrastination Scale (APS) yang disusun oleh McCloskey pada tahun 2011 berdasarkan aspek keyakinan psikologis mengenai kemampuan diri, distraksi, fak-tor sosial, pengelolaan waktu, inisiatif indi-vidu, dan kemalasan. Skala ini terdiri dari 25 aitem favorable dan unfavorable yang memiliki lima pilihan jawaban yakni Sangat Tidak Sesuai (STS), Tidak Sesuai (TS), Netral (N), Sesuai (S), dan Sangat Sesuai (SS). Skala adaptasi APS memiliki skor koefisien reliabilitas sebesar 0,904.

Uji hipotesis dilakukan menggunakan teknik analisis pearson's product-moment correlation dari Karl Pearson dengan bantuan software Statistical Product and Service Solution (SPSS) version 23.0 for Windows.

\section{Hasil}

Variabel problematic internet use memperoleh hasil rerata skor empirik sebesar 41,30 lebih rendah dibandingkan dengan skor hipotetiknya yaitu sebesar 42 . Sementara itu, pada variabel prokrastinasi akademik juga menunjukkan bahwa skor rerata empirik lebih rendah dari rerata skor hipotetiknya yaitu $63,97<66$. Berikut ini adalah Tabel 1 yang menjelaskan hasil deskripsi data penelitian.

Berdasarkan data di Tabel 1, dapat diketahui bahwa terdapat perbedaan antara skor empirik dan skor hipotetik. Kedua variabel baik problematic internet use maupun prokrastinasi akademik memiliki skor 
Tabel 1.

Data Hipotetis dan Data Empiris ( $\mathrm{N}=190)$

\begin{tabular}{|c|c|c|c|c|c|c|c|c|}
\hline \multirow[b]{2}{*}{ Variabel } & \multicolumn{4}{|c|}{ Nilai Hipotetik } & \multicolumn{4}{|c|}{ Nilai Empirik } \\
\hline & $\begin{array}{l}\text { Nilai } \\
\text { min. }\end{array}$ & $\begin{array}{l}\text { Nilai } \\
\text { maks. }\end{array}$ & Rerata & SD & $\begin{array}{l}\text { Nilai } \\
\text { min. }\end{array}$ & $\begin{array}{l}\text { Nilai } \\
\text { maks. }\end{array}$ & Rerata & SD \\
\hline $\begin{array}{l}\text { Problematic } \\
\text { Internet Use } \\
\end{array}$ & 14 & 70 & 42 & 9,33 & 15 & 69 & 41,30 & 9,04 \\
\hline $\begin{array}{l}\text { Prokrastinasi } \\
\text { Akademik }\end{array}$ & 22 & 110 & 66 & 14,67 & 30 & 101 & 63,97 & 12,59 \\
\hline \multicolumn{9}{|l|}{ Keterangan: } \\
\hline $\begin{array}{l}\text { Nilai min } \\
\text { Rerata }\end{array}$ & $\begin{array}{l}\text { : Nilai M } \\
\text { : Rata-rat }\end{array}$ & imum & & $\begin{array}{l}\text { Nilai m } \\
\text { SD }\end{array}$ & $: 5$ & $\begin{array}{l}\text { lai Maks } \\
\text { indar De }\end{array}$ & $\begin{array}{l}\text { mum } \\
\text { riasi }\end{array}$ & \\
\hline
\end{tabular}

Tabel 2.

Kategorisasi Skor Skala Problematic Internet Use

\begin{tabular}{|c|c|c|c|}
\hline Kategori & Skor & Jumlah & Persentase \\
\hline Sangat Tinggi & $56<x$ & 12 & $6,3 \%$ \\
\hline Tinggi & $46,67<x \leq 56$ & 44 & $23,2 \%$ \\
\hline Sedang & $37,33<x \leq 46,67$ & 83 & $43,7 \%$ \\
\hline Rendah & $28<x \leq 37,33$ & 40 & $21,1 \%$ \\
\hline Sangat Rendah & $x \leq 28$ & 11 & $5,8 \%$ \\
\hline \multicolumn{2}{|c|}{ Total } & 190 & $100 \%$ \\
\hline
\end{tabular}

rerata empirik yang lebih rendah dibandingkan dengan skor rerata hipotetiknya. Hal ini menunjukkan bahwa kecenderungan problematic internet use dan prokrastinasi akademik yang dimiliki subjek tergolong rendah.

Berdasarkan Tabel 2, hasil kategorisasi variabel problematic internet use menunjukkan bahwa sebagian besar subjek berada pada kategori sedang yakni sebanyak 83 subjek. 44 subjek lainnya berada pada kategori tinggi, 40 subjek selanjutnya berada pada kategori rendah, kemudian 12 subjek lainnya berada pada kategori sangat tinggi, dan sisanya adalah 11 subjek pada kategori sangat rendah.

Sementara itu, Tabel 3 menunjukkan hasil kategorisasi variabel prokrastinasi akademik yang menunjukkan bahwa sebagian besar subjek berada pada kategori sedang yakni sebanyak 85 subjek. Sebanyak
51 subjek berada pada kategori tinggi, 38 subjek berada pada kategori rendah, 10 dan terakhir ada 6 subjek yang berada pada kategori sangat rendah.

Uji hipotesis dilakukan dengan menggunakan teknik analisis pearson's product-moment correlation untuk mengetahui hubungan antara problematic internet use dengan prokrastinasi akademik. Tabel 4 menunjukkan hasil uji hipotesis tersebut. Berdasarkan Tabel 4, dapat diketahui bahwa analisis pearson's product-moment correlation antara problematic internet use dengan prokrastinasi akademik menghasil-kan $\mathrm{r}=$ 0,478 dengan taraf signifikansi $\mathrm{p}=0,000$ $(p<0,01)$. Hasil ini menunjukkan bahwa ada hubungan positif yang sangat signifikan antara akademik. Sehingga, hi-potesis yang diajukan dalam penelitian ini dapat diterima. Semakin tinggi tingkat problematic internet use maka akan semakin tinggi pula problematic 
Tabel 3.

Kategorisasi Skor Skala Prokrastinasi Akademik

\begin{tabular}{|c|c|c|c|}
\hline Kategori & Skor & Jumlah & Persentase \\
\hline Sangat Tinggi & $88,01<x$ & 10 & $5,3 \%$ \\
\hline Tinggi & $73,34<x \leq 88,01$ & 51 & $26,8 \%$ \\
\hline Sedang & $58,66<x \leq 73,34$ & 85 & $44,7 \%$ \\
\hline Rendah & $43,99<x \leq 58,66$ & 38 & $20,0 \%$ \\
\hline Sangat Rendah & $x \leq 43,99$ & 6 & $3,2 \%$ \\
\hline \multicolumn{2}{|c|}{ Total } & 190 & $100 \%$ \\
\hline
\end{tabular}

Tabel 4.

Hasil Uji Hipotesis

\begin{tabular}{ccc}
\hline Variabel & Pearson Correlation $(\mathbf{r})$ & $\mathbf{P}$ \\
\hline Prokrastinasi Akademik* Problematic Internet Use & 0,478 & 0,000 \\
\hline
\end{tabular}

internet use dengan prokrastinasi tingkat prokrastinasi akademik yang dimiliki. Sebaliknya, semakin rendah tingkat problematic internet use maka tingkat prokrastinasi akademik yang dimiliki akan semakin rendah.

Peneliti melakukan analisis tambahan berdasarkan jenis kelamin dan durasi penggunaan internet dalam satu hari. Berdasarkan hasil t-test, diketahui bahwa tidak terdapat perbedaan skor total problematic internet use $(\mathrm{p}=0,068)$ dan prokrastinasi akademik ( $p=0,286)$ di antara mahasiswa yang berjenis kelamin laki-laki dan perempuan, ditunjukkan dengan skor signifikansi $p>0,05$. Sementara itu berdasarkan hasil analisis uji beda, terdapat perbedaan pada skor total problematic internet use jika ditinjau dari durasi penggunaan internet dalam satu hari dengan skor signifikansi $0,000(p<0,05)$. Sebaliknya, tidak terdapat perbedaan pada skor total prokrastinasi akademik jika ditinjau dari durasi penggunaan internet dalam satu hari dengan skor signifikansi 0,438 ( $p>0,05)$.

\section{Diskusi}

Hasil analisis penelitian menunjukkan nilai rerata empirik variabel problematic internet use $(41,30)$ lebih rendah dari rerata hipotetiknya (42). Hal ini menujukkan bahwa rata-rata responden dari penelitian ini memiliki tingkat problematic internet use yang rendah karena angka rerata responden lebih kecil dari rerata skor yang digunakan. Begitu pula pada variabel prokrastinasi akademik yang menunjukkan bahwa nilai rerata empiriknya $(63,97)$ lebih rendah dari rerata hipotetiknya (66). Hal ini berarti rata-rata mahasiswa yang menjadi responden penelitian ini memiliki tingkat prokrastinasi akademik yang rendah karena angka rerata responden berada di bawah rerata skor yang digunakan.

Berkaitan dengan standar deviasi, baik variabel problematic internet use (SD empirik $=$ 9,04 ; SD hipotetik $=9,33$ ) maupun prokrastinasi akademik (SD empirik $=12,59$; SD hipotetik $=14,67)$ memiliki standar deviasi empirik yang lebih rendah dibandingkan standar deviasi hipotetiknya. Hal ini menujukkan bahwa skor problematic internet use dan prokrastinasi akademik memiliki variansi yang rendah atau bisa dikatakan bahwa respon subjek penelitian cenderung mirip.

Peneliti menemukan bahwa sebagian besar mahasiswa yang berpartisipasi dalam penelitian memiliki problematic internet use dalam kategori sedang (43,7\%). Sedangkan subjek penelitian lainnya terdistribusi ke dalam kategori sangat rendah (5,8\%), kategori rendah $(21,1 \%)$, kategori tinggi $(23,2)$ dan kategori sangat tinggi (6,3\%). 
Sementara itu, pada variabel prokrastinasi akademik ditemukan bahwa mayoritas subjek penelitian memiliki prokrastinasi akademik yang sedang $(44,7 \%)$. Sedangkan subjek penelitian lainnya terdistribusi ke dalam kategori sangat rendah $(3,2 \%)$, kategori rendah $(20,0 \%)$, kategori tinggi $(26,8)$, dan kategori sangat tinggi $(5,3 \%)$.

Hasil dari analisis data penelitian menunjukkan bahwa terdapat hubungan yang sangat signifikan antara problematic internet use dengan prokrastinasi akademik dengan nilai korelasi (r) sebesar 0,478 dan taraf signifikansi $p=0,000(p<0,01)$. Hasil analisis ini menujukkan nilai positif yang dapat diartikan bahwa hubungan antara variabel problematic internet use dengan prokrastinasi akademik bersifat positif, yang berarti bahwa semakin tinggi tingkat problematic internet use maka akan semakin tinggi pula tingkat prokrastinasi akademik yang dimiliki. Sebaliknya, semakin rendah tingkat problematic internet use maka tingkat prokrastinasi akademik yang dimiliki akan semakin rendah.

Hasil pada penelitian ini sejalan dengan penelitian yang dilakukan Mohammadi, et al. (2015) pada 380 mahasiswa EFL di University of Guilan yang menemukan bahwa terdapat hubungan positif antara prokrastinasi akademik dengan penggunaan internet bermasalah. Nilai koefisien korelasinya adalah sebesar 0,472 dengan nilai signifikansi sebesar 0,000 .

Penelitian yang dilakukan Brate (2017) menemukan hasil bahwa faktor penyebab prokrastinasi yaitu ketakutan akan kegagalan, keenganan mengerjakan tugas, dan kemalasan menjadi prediktor yang signifikan terhadap kecenderungan penggunaan internet bermasalah. Odaci (2011) menjelaskan bahwa mahasiswa sedang menjalani masa kritis dalam perkembangan sosial dan emosinya yang menjadikan mahasiswa sebagai kelompok yang rentan akan ketergantungan internet. Fakta bahwa internet adalah sumber yang ber- guna dalam tugas akademik tidak bisa menutupi dampak negatif yang biasa disebut sebagai problematic internet use.

Thatcher, et al., (2008) menambahkan bahwa problematic internet use ini menjadi salah satu tanda individu merasa bosan, tidak termotivasi, dan tidak yakin akan kemampuannya untuk melaksanakan tugas di dunia nyata sehingga individu melarikan diri dari pekerjaannya menuju internet. Internet menyajikan berbagai distraktor menarik seperti mengirim pesan secara online, mengakses berita olahraga, mengakses berbagai macam hiburan, dan menyalurkan hobi yang menjadikan internet sebagai salah satu media untuk melakukan prokrastinasi akademik karena kecepatan dan kemudahan akses yang diberikan.

Penggunaan internet yang berlebihan dapat mengakibatkan individu mengabaikan tugas yang seharusnya dikerjakan sehingga mengakibatkan perilaku prokrastinasi dan menyebabkan masalah dalam kehidupan sehari-hari, seperti masalah fisik atau psikologis (Lay, 1988; Caplan dan High, 2011).

Berdasarkan data demografis dan informasi tambahan yang didapatkan melalui pengambilan data, peneliti melakukan analisis tambahan untuk melihat perbedaan variabel problematic internet use dan prokrastinasi akademik antara kelompok subjek lakilaki dan perempuan. Hasil menunjukkan bahwa tidak ada perbedaan skor baik pada variabel problematic internet use $(\mathrm{p}=0,068 ; \mathrm{p}>$ $0,05)$ dan variabel prokrastinasi akademik ( $p$ $=0,286 ; \mathrm{p}>0,05$ ) antara mahasiswa yang berjenis kelamin laki-laki dan perempuan. Meskipun demikian, ditemukan hasil bahwa rerata skor problematic internet use $(41,91)$ dan skor prokrastinasi akademik $(64,47)$ pada subjek perempuan lebih tinggi dibandingkan rerata skor problematic internet use $(38,95)$ dan skor prokrastinasi akademik $(62,05)$ pada subjek laki-laki.

Temuan ini berbeda dengan penelitian sebelumnya yang dilakukan Saleem, et al. 
(2015) pada 400 subjek penelitian yang terdiri dari 200 subjek perempuan dan 200 subjek laki-laki, yang menemukan bahwa rerata skor adiksi internet pada subjek laki-laki $(45,84)$ lebih tinggi daripada skor adiksi internet pada subjek perempuan $(43,49)$. Sementara itu, skor prokrastinasi pada subjek perempuan $(35,03)$ menunjukkan skor yang lebih tinggi dibandingkan dengan skor prokrastinasi pada subjek laki-laki $(34,49)$. Perbedaan hasil ini dapat terjadi karena perbedaan proporsi subjek penelitian lakilaki dan perempuan. Di dalam penelitian ini, subjek perempuan lebih mendominasi dibandingkan subjek laki-laki.

Peneliti juga melakukan analisis tambahan untuk melihat perbedaan tingkat variabel problematic internet use dan prokrastinasi akademik berdasarkan durasi penggunaan internet dalam satu hari. Hasil analisis data menunjukkan bahwa pada variabel problematic internet use, terdapat perbedaan problematic internet use yang signifikan berdasarkan durasi penggunaan internet dalam satu hari $(F=7,604, p=0,000$; $p<0,05)$. Sementara itu pada variabel prokrastinasi akademik menunjukkan bahwa tidak ada perbedaan prokrastinasi akademik yang signifikan berdasarkan durasi penggunaan internet dalam satu hari $(\mathrm{F}=$ 0,908, $\mathrm{p}=0,438 ; \mathrm{p}>0,05$ ).

Penelitian ini tentunya masih memiliki keterbatasan yaitu skala yang digunakan untuk mengukur variabel problematic internet use yaitu skala adaptasi dari Generalized Problematic Internet Use Scale 2 (GPIUS-2) belum dapat mengukur proble-matic internet use secara menyeluruh karena penjabaran aitemnya kurang sesuai dengan aspek yang dicantumkan.

\section{Kesimpulan}

Berdasarkan hasil penelitian dan analisis yang telah dilakukan, dapat diambil kesimpulan bahwa terdapat hubungan positif yang sangat signifikan antara problematic internet use dengan prokrastinasi akademik pada mahasiswa. Hubungan antara kedua variabel ini bersifat positif, yang berarti semakin tinggi tingkat problematic internet use, maka semakin tinggi pula tingkat prokrastinasi akademik yang dilakukan oleh mahasiswa. Begitu pula sebaliknya, semakin rendah tingkat problematic internet use, maka semakin rendah pula tingkat prokrastinasi akademik yang dilakukan oleh mahasiswa. Oleh karena itu, dapat dikatakan bahwa hipotesis dalam penelitian ini diterima.

Analisis tambahan yang dilakukan pada penelitian ini menemukan bahwa tidak ada perbedaan tingkat problematic internet use dan prokrastinasi akademik pada mahasiswa berjenis kelamin perempuan dan laki-laki. Sementara itu, pada analisis tambahan berdasarkan durasi penggunaan internet dalam satu hari, ditemukan perbedaan problematic internet use yang signifikan berdasarkan durasi penggunaan internet dalam satu hari. Sebaliknya, pada variabel prokrastinasi akademik tidak ditemukan perbedaan tingkat prokrastinasi akademik yang signifikan berdasarkan durasi penggunaan internet dalam satu hari.

\section{Saran}

Salah satu cara yang dapat digunakan mahasiswa dalam menghadapi problematic internet use dan prokrastinasi akademik adalah dengan mempertahankan serta meningkatkan manajemen diri seperti membuat target yang spesifik, mengelola waktu luang, dan terbuka untuk kritik dan saran dari pihak luar. Kemudia bagi peneliti yang akan meneliti tema serupa, disarankan untuk lebih kritis dalam proses pemilihan skala, terutama apabila akan menggunakan skala adaptasi dari luar negeri. Hal ini perlu dilakukan agar penelitian selanjutnya dapat benar-benar mengukur variabel dengan tepat. 


\section{Daftar Pustaka}

Beard, K. W., \& Wolf, E. M. (2001). Modification in the proposed diagnostic criteria for internet addiction. Cyberpsychology \& Behavior, 4(3), 377-383. doi: 10.1089/109493101300210286

Brate, A. T. (2017). Compulsive internet use and academic procrastination: Significant comparative, correlative and predicting indicators in a Romanian student sample. International Conference Knowledge-Based Organization, 23(2), 251-255. doi: 10.1515/kbo-2017-0122

Burka, J. B. \& Lenora M. Y. (2008). Procrastination: Why you do it, what to do about it now. USA: Da Capo Press.

Caplan, S. E. (2010). Theory and measurement of generalized problematic internet use: A two-step approach. Computers in Human Behavior, 26, 1089-1097.

Caplan, S. E., \& High, A. C. (2011). Online social interaction, psychosocial wellbeing, and problematic internet use. Dalam K. S. Young, \& C. N. de Abreu, Internet addiction a handbook and guide to evaluation and treatment (hal. 35-53). New Jersey: John Wiley \& Sons, Inc.

Chen, Y. F., \& Peng, S. (2008). University student's internet use and its relationships with academic performance, interpersonal relationships, psychosocial adjustment, and self-evaluation. Cyber Psychology $\mathcal{E}$ Behavior, 11(4), 467-471. doi: 10.1089/cpb.2007.0128.

Davis, R. A. (2001). A cognitive-behavioral model of pathological internet use. Computers in Human Behavior, 17, 187195. doi: $10.1016 / S 0747-5632(00) 00041-8$

Diomidous, M., Chardalias, K., Magita, A., Koutonias, P., Panagiotopolou, P., \& Mantas, J. (2016). Social and psychological effects of the internet use. Acta Informatica Medica, 24(1), 6668. doi: $10.5455 /$ aim.2016.24.66-68

Ferrari, J. R., Johnson, J. L., \& McCown, W. G. (1995). Procrastination and task avoidance: Theory, research, and treatment. New York: Plenum Press.

Knaus, E. W. (2010). End procrastination now! Get it done with a proven psychological approach. United States: McGraw-Hill Companies.

Lavoie, J., \& Pychyl, T. (2001). Cyberslacking and the procrastination superhighway: A web-based survey of online procrastination, attitudes, and emotion. Social Science Computer Review, 19(4), 431-444. doi: 10.1177/089443930101900403

Lay, C. H. (1988). The relationship of procrastination and optimism to judgments of time to complete an essay and anticipation of setbacks. Journal of Social Behavior \& Personality, 3(3), 201214.

McCloskey, J. D. (2011). Finally, my thesis on academic procrastination. (Unpublished Master Thesis), The University of Texas at Arlington, Master of Science in Psychology, Arlington U.S.

Mohammadi, M., Tahriri, A., \& Hassaskhah, J. (2015). The relationship between internet use and academic procrastination of EFL learners across years of study. International Journal of Applied Linguistics \& English Literature, 4(1), 231-241. doi: 10.7575/aiac.ijalel.v.4n.1p.231

Negara, P. P. (2013). Hubungan antara usia, jenis kelamin, impulsiveness, mood, timing of rewards and punishments, dan task aversiveness dengan prokrastinasi akademik mahasiswa. Tesis (tidak dipublikasikan), Fakultas Psikologi, Universitas Gadjah Mada.

Odaci, H. (2011). Academic self-efficacy and academic procrastination as predictors of problematic internet use in university students. Computers $\mathcal{E}$ 
Education, 57(1), 1109-1113. doi: 10.1016/j.compedu.2011.01.005

Saleem, M., Owaisi, A. M., \& Tufail, M. W. (2015). Internet addiction: It's impact on procrastination of higher learning students in Pakistan. The Sindh University Journal of Education, 44(2), 205-230.

Santrock, J. W. (2008). Educational psychology fifth edition. New York: The McGrawHill Companies.

Solomon, L. J., \& Rothblum, E. (1984). Academic procrastination: Frequency and cognitive-behavioral correlates. Journal of Counseling Psychology, 31(4), 503-509. doi: 10.1037/0022$\underline{0167.31 .4 .503}$

Steel, P. (2007). The nature of procrastination: A meta-analytic and theoretical review of quintessential sel-regulatory failure. Psychological Bulletin, 133(1), 65-94. doi: 10.1037/0033-2909.133.1.65

Steel, P., \& Klingsieck, K. B. (2015). Procrastination. International Encyclopedia of the Social \& Behavioral Sciences, 2 nd edition, 19, 73-78. Oxford: Elsevier.

Sugiarto, A. L. (2017). Hubungan tingkat kesepian dengan penggunaan internet yang bermasalah pada mahasiswa. Skripsi (tidak dipublikasikan), Fakultas Psikologi, Universitas Gadjah Mada.

Thatcher, A., Wretschko, G., \& Fridjhon, P. (2008). Online flow experiences, problematic internet use and internet procrastination. Computer in Human Behavior, 24(5), 2236-2254. doi: $\underline{10.1016 / j . c h b .2007 .10 .008}$ 